\section{Infant mortality in the Federal District, Brazil: time trend and socioeconomic inequalities}

\author{
Mortalidade infantil no Distrito Federal, Brasil: \\ tendência temporal e desigualdades \\ sócio-econômicas
}

\footnotetext{
1 Secretaria de Atenção à Saúde, Ministério da Saúde, Brasília, Brasil.

2 Faculdade de Ciências da Saúde, Universidade de Brasília, Brasília, Brasil.

Correspondence R. A. Monteiro Departamento de Ações Programáticas Estratégicas, Secretaria de Atenção à Saúde, Ministério da Saúde. Esplanada dos Ministérios,

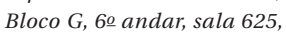
Brasília, DF 70058-900, Brasil. renata.monteiro@globo.com renata.monteiro@saude.gov.br
}

\begin{abstract}
This study examined the trend in the infant mortality rate in the Federal District of Brazil (or Greater Metropolitan Brasilia, the national capital) from 1990 to 2000, analyzing the rate according to 5 administrative areas stratified by mean family income, from 1996 to 2000. An ecological time-series study was conducted using the Information Systems on Live Births and Mortality, produced by the Brazilian Ministry of Health. The infant mortality rate (IMR) decreased by $45.2 \%$ from 1990 to 2000, from 26.3 per 1000 live births to 14.4 , or a mean annual reduction of 5.34\% ( $\left.R^{2}=0.9397 ; p<0.0001\right)$. During this period there was a higher proportion of neonatal deaths. However, a higher percentage change occurred in the post-neonatal period (-59.0\%, $R^{2}$ $=0.8452, p<0.0001)$. Investigation of the IMR in the various areas of the Federal District showed $a$ reduction in differences among the regions with respect to the component rates; however, substantial disparities persisted in relation to the income variable. The results suggest the need for effective interventions in the determinants of neonatal and post-neonatal mortality in order to improve maternal and infant health in all socioeconomic groups in the Federal District.
\end{abstract}

Infant Mortality; Maternal and Child Health; Information Systems; Ecological Studies
Renata Alves Monteiro 1

Bethsáida de Abreu Soares Schmitz 2

\section{Introduction}

One of the principal indicators of quality of life and health for a given community is the infant mortality rate (IMR), which is highly sensitive for measuring social well-being and is directly related to the population's environmental and socioeconomic conditions 1,2 . IMR measures the risk of a newborn dying during the first year of life ${ }^{3}$.

Infant mortality has undergone a continuous decline in recent years, but at different rates according to country. While the IMR is low in developed countries like Japan (4.0 per 1,000 live births in 1995) 4 , the current levels in developing countries like Brazil are higher than those in developed countries in the 1960s (Brazil's IMR in 2000 was 27.1) 5

Meanwhile, the decline in Brazil's IMR has been rather tenuous as compared to developing countries with similar socioeconomic characteristics, and regional disparities between different population groups have actually increased $6,7,8,9,10$. The difference in infant mortality between the South and Northeast of Brazil, which was $40 \%$ in the 1930 s, increased to $140 \%$ by the late 1970 s and $300 \%$ by the late 1990 s 9 .

The Federal District, where the national capital is located, has shown a downward trend in IMR to levels similar to those in various States of the country, from 41.0 per 1,000 live births in 1980 to 23.8 in 198911. 
The present study aimed to characterize infant mortality trends in the Federal District from 1990 to 2000, analyzing differences in overall IMR and component rates with regard to family socioeconomic status in the administrative areas comprising the Federal District.

\section{Methods}

The Federal District is located in the Central West region of Brazil and has an area of $5,789 \mathrm{~km}^{2}$, currently divided into 19 administrative areas. According to the 2000 census, the Federal District had 2,051,000 inhabitants, approximately $2 \%$ infants (<1 year of age) 12,13 .

In 1998, the Federal District ranked first, ahead of all the States in Brazil, in the human development index (HDI). The United Nations recommends the HDI as an overall indicator of human development based on income, education, and life expectancy 14 .

The Federal District HDI was 0.869 in 1998 , indicating a high degree of human development, higher than the overall index for Brazil in 2000 (0.757), when the country ranked 73rd worldwide 10,14 .

An ecological time-series study was conducted, based on data from the Mortality Information System and Live Births Information System coordinated by the Brazilian Ministry of Health ${ }^{15}$. The quality of Federal District mortality data is considered adequate 16,17 . The infant mortality rate has been calculated directly since 1999, although the data quality had been proven even earlier.

The study population consisted of all recorded deaths of infants ( $<1$ year of age) in the Federal District from 1990 to 2000. The study adopted the definitions of infant mortality and the component rates as proposed by the World Health Organization (WHO) and Brazilian Ministry of Health 18.

Since there was a marked change in the composition of the administrative areas in the Federal District from 1990 to 1995, it was not possible to stratify by administrative area before 1995. The first study of the decentralized Federal District based on administrative areas was performed in 1996, when separate data had become available for the currently existing administrative areas under the Federal District's spatial apportionment.

To determine the development of spatial differences in infant mortality in the Federal District, the administrative areas were aggregated in 5 groups as of 1996, according to mean family income as suggested by the Committee for the Development of the Central Plateau (CODEPLAN) 19 and described in Table 1. Data on family income were obtained by CODEPLAN through the Federal District Socioeconomic Family Survey, using a probabilistic sample. The regions formed by the 5 groups of administrative areas do not always form areas with common borders.

The 1990-2000 trends in IMR and component rates by age for the five groups of administrative areas and the entire Federal District were analyzed with an exponential regression model, which was both well-adapted to the data and statistically powerful 20 .

Besides the mean annual decline (\%), the determination coefficient $\left(\mathrm{R}^{2}\right)$ was also analyzed, with an $\alpha$ of less than 0.05 considered significant To analyze the relationship between income spatial groups, the infant mortality rates ratio was obtained, using the mortality rate for the highest family income group as the reference.

\section{Results}

The IMR has declined consistently in the Federal District in recent years. From 1990 to 2000 there was a $45.2 \%$ decline in IMR, from 26.3 to 14.4 per 1,000 live births. As shown in Table 1, the mean annual decrease was $5.34 \%$. The exponential IMR reduction was 0.0533 per year during that period, showing a representative decline and maintaining the trend from the previous decade (Table 2 and Figure 1).

Of the recorded infant deaths, the highest proportion occurred during the neonatal period, but the largest decline was post-neonatal. The post-neonatal mortality rate in 1990 was 10.5 per 1,000 live births, dropping to 4.3 in 2000 , or a decrease of $59 \%$ and a mean annual drop of $7.8 \%$. The exponential trend was -0.0437 per year $\left(\mathrm{R}^{2}=\right.$ 0.852; $\mathrm{p}<0.001)$.

During the period studied, the $35.1 \%$ change in the neonatal mortality rate was due to a $41.5 \%$ drop in early neonatal mortality, since late neonatal mortality did not change $\left(\mathrm{R}^{2}=0.0046, \mathrm{p}=\right.$ 0.8 . The mean annual decrease in the neonatal mortality rate was $3.85 \%$, as compared to $4.76 \%$ in the early neonatal mortality rate.

Infant mortality provides evidence of key socioeconomic differences among the various administrative areas in the Federal District, although these differences in the IMR and component rates have been decreasing over the years (Tables 3 and 4).

The infant mortality trend in Group 1, with the highest income in the Federal District, showed an increase in IMR and component rates from 1996 to 2000, with the exception of early neonatal mortality, which declined by $5.4 \%$, or $1.14 \%$ per year. However, only the positive changes in late 
Stratification of administrative areas in the Federal District, Brazil, according to mean monthly family income.

\begin{tabular}{|c|c|c|c|c|c|c|}
\hline \multirow[t]{2}{*}{ Economic class * } & \multirow[t]{2}{*}{ Administrative area } & \multirow{2}{*}{$\begin{array}{c}\text { Mean monthly } \\
\text { family income ** }\end{array}$} & \multirow{2}{*}{$\begin{array}{l}\text { Mean monthly } \\
\text { family income } \\
\text { for group ** }\end{array}$} & \multirow{2}{*}{$\begin{array}{c}\text { Percentage of total } \\
\text { Federal District } \\
\text { population } * \star \star\end{array}$} & \multicolumn{2}{|c|}{ Live births } \\
\hline & & & & & 1996 & 2000 \\
\hline \multirow[t]{3}{*}{ Group 1} & I-Brasília & 32.5 & & & & \\
\hline & XVI - Lago Norte & 52.7 & & & & \\
\hline & XVIII - Lago Sul & 65.8 & 50.3 & 12.3 & 4,452 & 4,166 \\
\hline \multirow[t]{4}{*}{ Group 2} & III - Taguatinga & 16.1 & & & & \\
\hline & VIII - Núcleo Bandeirante & 18.1 & & & & \\
\hline & X-Guará & 20.7 & & & & \\
\hline & XI - Cruzeiro & 24.0 & 19.7 & 22.5 & 9,348 & 9,527 \\
\hline \multirow[t]{4}{*}{ Group 3} & II - Gama & 9.0 & & & & \\
\hline & V-Sobradinho & 11.0 & & & & \\
\hline & XVII - Riacho Fundo & 9.8 & & & & \\
\hline & XIX - Candangolândia & 11.4 & 10.3 & 15.5 & 7,475 & 7,664 \\
\hline \multirow[t]{4}{*}{ Group 4} & IV - Brazlândia & 6.5 & & & & \\
\hline & VI - Planaltina & 6.1 & & & & \\
\hline & IX - Ceilândia & 7.6 & & & & \\
\hline & XII - Samambaia & 7.6 & 7.0 & 34.5 & 18,070 & 18,142 \\
\hline \multirow[t]{4}{*}{ Group 5} & VII - Paranoá & 4.6 & & & & \\
\hline & XIII - Santa Maria & 5.0 & & & & \\
\hline & XIV - Agrovila São Sebastião & 5.3 & & & & \\
\hline & XV - Recanto das Emas & 4.7 & 4.9 & 15.2 & 5,864 & 7,305 \\
\hline
\end{tabular}

* Companhia do Desenvolvimento do Planalto Central 19.

** In times the monthly minimum wage;

*** Anuário Estatístico do Distrito Federal 12

Note: The monthly minimum wage in February-April 1997 was approximately U\$107 (R\$112).

neonatal mortality $(\mathrm{p}=0.002)$ and IMR $(\mathrm{p}=0.02)$ were significant. Meanwhile, in 1996 Group 1 had the lowest IMR, compared to the other 4 groups (Table 4). In 2000, its IMR was only higher than that of Group 2 (11\%), which included the second highest-income areas, next to Group 1.

In Group 2, every component of infant mortality declined, but the difference in the postneonatal mortality rate was not statistically significant ( $\mathrm{p}>0.05)$.

Group 3 showed the same infant mortality trend as in Group 1, but to a lesser degree and not statistically significant ( $p>0.05)$, indicating stagnation in the rates during the 5 -year period. Still, the gap between mortality rates in Groups 1 and 3 decreased: in 1996, the IMR in Group 3 had been $84 \%$ higher than in Group 1, but by 2000 the difference was only $17 \%$.

The IMR in the other income groups underwent a statistically significant decrease $(p<0.05)$. However, when the infant mortality components were analyzed separately in Groups 4 and 5, al- though there was some percentage change in all of them, a significant reduction only occurred in early neonatal mortality in Group 4 ( $\mathrm{p}=0.02$ ).

Based on data in Table 3, the largest reduction in IMR and the component rates was in Group 2, followed by Group 5, the latter having the lowest income in the Federal District. Unlike the other groups, 2 and 5 showed the greatest drop in IMR, with $-45.1 \%$ and $-30.4 \%$, respectively, in the late neonatal component ( $\mathrm{p}>0.05)$.

Despite the increase in IMR in Groups 1 and 3 from 1996 to 2000, the highest IMR in the Federal District was in the lowest income group (number 5). However, the difference between Group 5 and that with the lowest IMR decreased during the period studied ( $155 \%$ in 1996 , but only $18 \%$ by 2000).

As for the infant mortality components, the largest decline in neonatal mortality was in Group 2 ( $p=0.004)$, which had the lowest neonatal mortality rate in the Federal District in 2000 (7.1/1,000 live births). 
Table 2

Results of exponential regression analysis of infant mortality rate and its components. Federal District, Brazil, 1990 and 2000.

\begin{tabular}{|c|c|c|c|c|c|c|c|c|c|}
\hline \multirow[t]{2}{*}{ Mortality rate } & \multicolumn{2}{|c|}{ Number of deaths } & \multicolumn{3}{|c|}{$\begin{array}{c}\text { Mortality rate } \\
\text { (per } 1,000 \text { live births) }\end{array}$} & \multirow[t]{2}{*}{$\begin{array}{c}\text { Mean annual } \\
\text { decline (\%) }\end{array}$} & \multirow[t]{2}{*}{$\begin{array}{l}\text { Exponential } \\
\text { model }\end{array}$} & \multirow[t]{2}{*}{$\mathbf{R}^{2}$} & \multirow[t]{2}{*}{$p$ value } \\
\hline & 1990 & 2000 & 1990 & 2000 & $\Delta \%$ & & & & \\
\hline Early neonatal & 474 & 365 & 13.0 & 7.6 & -41.5 & -4.76 & $Y=13.033 e-0.0437 x$ & 0.8619 & $<0.0001$ \\
\hline Late neonatal & 89 & 113 & 2.4 & 2.4 & - & - & $Y=2.6744 e^{-0.0019 x}$ & 0.0046 & 0.8 \\
\hline Neonatal & 563 & 478 & 15.4 & 10.0 & -35.1 & -3.85 & $Y=15.703 e-0.0354 x$ & 0.8292 & $<0.0001$ \\
\hline Post-neonatal & 384 & 207 & 10.5 & 4.3 & -59.0 & -7.80 & $Y=9.7937 e-0.0437 x$ & 0.8452 & $<0.0001$ \\
\hline \multirow[t]{2}{*}{ Infant * } & 960 & 691 & 26.3 & 14.4 & -45.2 & -5.34 & $Y=26.496 e-0.0533 x$ & 0.9397 & $<0.0001$ \\
\hline & 1990 & 2000 & & & & & & & \\
\hline Live births & 36,460 & 47,982 & & & & & & & \\
\hline
\end{tabular}

R2: Determination coefficient;

* Including deaths of infants (< one year) with unknown age (1.3\% in 1990; $0.9 \%$ in 2000$)$.

\section{Figure 1}

Infant mortality rate and components. Federal District, Brazil, 1990-2000.

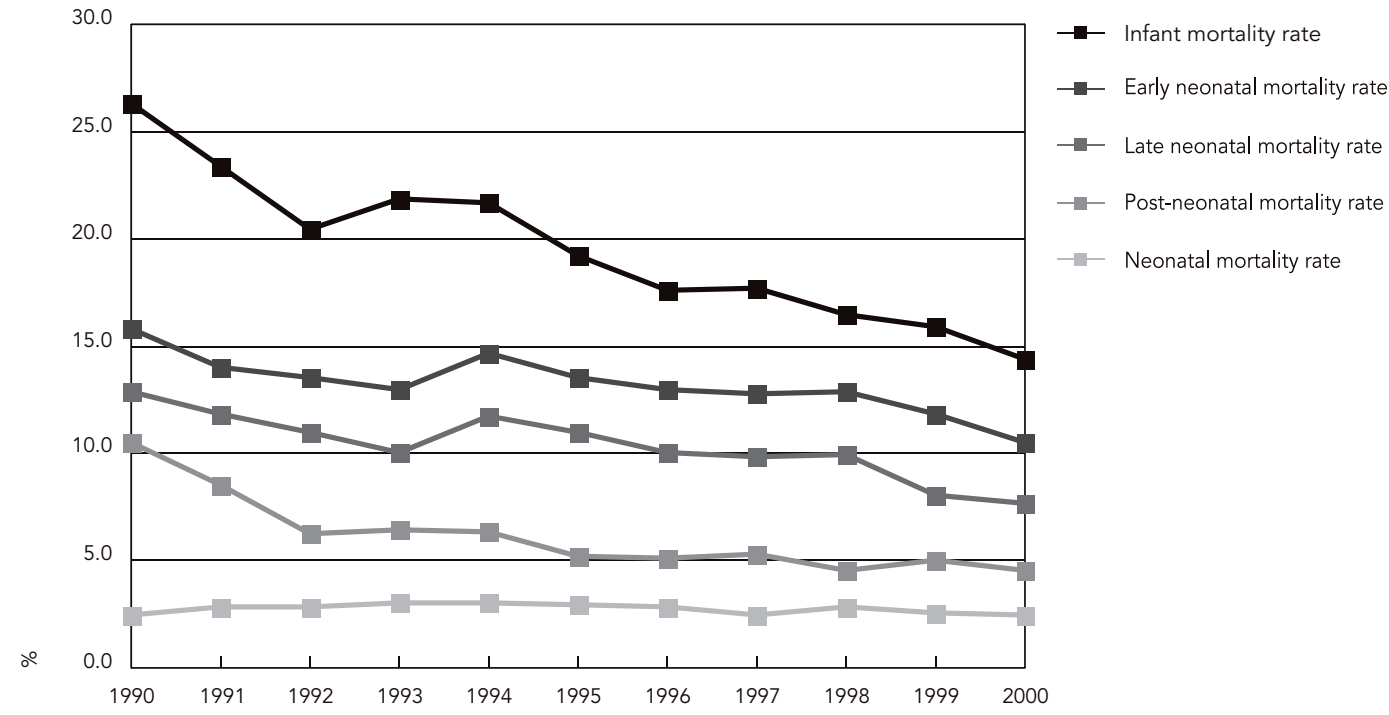

The greatest reductions in the post-neonatal mortality rate were in Groups $4(\mathrm{p}=0.02)$ and 2 $(\mathrm{p}>0.05)$, and the greatest increase was in Group $1(131.5 \%)$, although not significant ( $p>0.05)$. Group 1 thus had the lowest post-neonatal mortality rate in the Federal District in 2000 (3.1 per 1,000 live births).

\section{Discussion}

The infant mortality rate reflects a population's living conditions, nutrition, and health, as well as aspects related to the social responsibility of a given society and its government, since it indicates the odds of infant survival 21 . 
Infant mortality rate and components in 5 groups of administrative areas based on mean monthly family income.

Federal District, Brazil, 1996 and 2000.

\begin{tabular}{|c|c|c|c|c|c|c|c|}
\hline \multirow{2}{*}{ Mortality rate } & \multicolumn{2}{|c|}{ Number of deaths } & \multicolumn{3}{|c|}{ Mortality rate * } & \multirow{2}{*}{$\begin{array}{c}\text { Mean annual } \\
\text { decline (\%) }\end{array}$} & \multirow[t]{2}{*}{$p$ value } \\
\hline & 1996 & 2000 & 1996 & 2000 & $\Delta \%$ & & \\
\hline \multicolumn{8}{|l|}{ Group 1} \\
\hline Early neonatal & 24 & 21 & 5.4 & 5.1 & -5.4 & -1.14 & 0.82 \\
\hline Late neonatal & 4 & 18 & 0.9 & 4.3 & 380.9 & 36.72 & 0.002 \\
\hline Neonatal & 28 & 39 & 6.3 & 9.4 & 49.8 & 8.33 & 0.11 \\
\hline Post-neonatal & 6 & 13 & 1.3 & 3.1 & 131.5 & 18.98 & 0.08 \\
\hline Infant & 34 & 52 & 7.6 & 12.5 & 63.4 & 10.46 & 0.02 \\
\hline \multicolumn{8}{|l|}{ Group 2} \\
\hline Early neonatal & 78 & 53 & 8.3 & 5.6 & -33.3 & -7.57 & 0.02 \\
\hline Late neonatal & 25 & 14 & 2.7 & 1.5 & -45.1 & -11.09 & 0.07 \\
\hline Neonatal & 103 & 67 & 11.0 & 7.1 & -35.6 & -8.38 & 0.004 \\
\hline Post-neonatal & 50 & 38 & 5.3 & 4.0 & -25.4 & -5.47 & 0.17 \\
\hline Infant ** & 153 & 107 & 16.3 & 11.1 & -31.9 & -7.40 & 0.002 \\
\hline \multicolumn{8}{|l|}{ Group 3} \\
\hline Early neonatal & 66 & 62 & 8.8 & 8.1 & -8.4 & -1.64 & 0.62 \\
\hline Late neonatal & 9 & 18 & 1.2 & 2.3 & 95.1 & 13.90 & 0.10 \\
\hline Neonatal & 75 & 80 & 10.0 & 10.4 & 4.0 & 0.79 & 0.8 \\
\hline Post-neonatal & 30 & 32 & 4.0 & 4.2 & 4.0 & 0.98 & 0.9 \\
\hline Infant & 105 & 112 & 14.0 & 14.6 & 4.0 & 0.84 & 0.77 \\
\hline \multicolumn{8}{|l|}{ Group 4} \\
\hline Early neonatal & 156 & 129 & 8.6 & 7.1 & -17.6 & -3.76 & 0.1 \\
\hline Late neonatal & 56 & 47 & 3.1 & 2.6 & -16.4 & -3.46 & 0.36 \\
\hline Neonatal & 212 & 176 & 11.7 & 9.7 & -17.3 & -3.68 & 0.06 \\
\hline Post-neonatal & 106 & 76 & 5.9 & 4.2 & -28.6 & -6.57 & 0.02 \\
\hline Infant & 318 & 252 & 17.6 & 13.9 & -21.1 & -4.61 & 0.005 \\
\hline \multicolumn{8}{|l|}{ Group 5} \\
\hline Early neonatal & 56 & 55 & 9.5 & 7.5 & -21.2 & -4.62 & 0.21 \\
\hline Late neonatal & 15 & 13 & 2.6 & 1.8 & -30.4 & -7.09 & 0.34 \\
\hline Neonatal & 71 & 68 & 12.1 & 9.3 & -23.1 & -5.13 & 0.12 \\
\hline Post-neonatal & 43 & 40 & 7.3 & 5.5 & -25.3 & -5.50 & 0.18 \\
\hline Infant & 114 & 108 & 19.4 & 14.8 & -24.0 & -5.27 & 0.04 \\
\hline
\end{tabular}

* Per 1,000 live births;

** Including deaths of infants (< one year) with unknown age (in 1996, none; in group 2, 0.9\% in 2000).

Due to the effectiveness of measures to decrease the IMR (specific actions in health and education), infant mortality has been treated as a priority health problem in developed countries as well, where very low IMR levels have been reached.

Income is one of the most widely used measurements of socioeconomic status with a direct impact on infant mortality 22. In Andrade et al. 22, where income and schooling were chosen as indicators to detect inequalities in perinatal mortality, income was the variable that most explained IMR inequalities. This is one reason why the current study used this variable, while rec- ognizing that different realities can be obtained, depending on the variables selected to measure living conditions 23 .

There was a real and consistent decline in infant mortality in the Federal District, currently showing among the lowest infant mortality, neonatal mortality, and post-neonatal mortality rates in Brazil 18. In the 1990s, the mean annual decline in the Federal District was the same as for the previous decade (5.3\%) 11, but there was no apparent increase in this downward trend in the IMR. None of the States of Brazil with low IMR showed a mean annual decline close to that of the Federal District, with the greatest drop (5.27\%) 
Ratio of mortality rates among 5 groups of administrative areas based on mean monthly family income.

Federal District, Brazil, 1996 and 2000.

\begin{tabular}{|c|c|c|c|c|c|c|c|c|}
\hline \multirow[t]{3}{*}{ Mortality } & \multicolumn{8}{|c|}{ Ratio of mortality rates among 5 groups of administrative areas in Federal District } \\
\hline & \multicolumn{2}{|c|}{$2 / 1$} & \multicolumn{2}{|c|}{$3 / 1$} & \multicolumn{2}{|c|}{$4 / 1$} & \multicolumn{2}{|c|}{$5 / 1$} \\
\hline & 1996 & 2000 & 1996 & 2000 & 1996 & 2000 & 1996 & 2000 \\
\hline Early neonatal & 1.54 & 1.10 & 1.63 & 1.59 & 1.59 & 1.39 & 1.76 & 1.47 \\
\hline Late neonatal & 3.00 & 0.35 & 1.33 & 0.53 & 3.44 & 0.60 & 2.89 & 0.42 \\
\hline Neonatal & 1.75 & 0.76 & 1.59 & 1.11 & 1.86 & 1.03 & 1.92 & 0.99 \\
\hline Post-neonatal & 4.08 & 1.29 & 3.08 & 1.35 & 4.54 & 1.35 & 5.62 & 1.77 \\
\hline Infant & 2.14 & 0.89 & 1.84 & 1.17 & 2.32 & 1.11 & 2.55 & 1.18 \\
\hline
\end{tabular}

occurring in the city of Belo Horizonte; however infant mortality in this city was higher than in the Federal District (22.1 in 1998) 24.

Meanwhile, the overall trend was not observed in all administrative areas of the Federal District. The results for Group 1, consisting of the most highly developed administrative areas, was unexpected, as was the convergence of rates (among groups of administrative areas) towards values close to 15.0 per 1,000 live births. This may have resulted from the saturation of effects of some environmental interventions and various previously achieved benefits 21 . Goldani et al. 25 observed a similar situation (in an economically better-off group) in a city in São Paulo State.

From 1990 to 2000, the Federal District experienced changes in both its geographic structure and demographic make-up. The population increased by $21.6 \%$, largely due to migration to the National capital. New administrative areas (also known as "satellite cities") emerged from the reapportionment of existing areas and the formation of new ones to absorb the rapid population growth. Meanwhile, there was no significant improvement in factors determining the quality of life, like income, housing, and education, and there was a lack of proportional growth in available health services; for example, from 1995 to 1999 the number of hospital beds decreased by $13.7 \% 12$

The largest proportion of infant deaths occurred during the neonatal period, a global trend accompanying the reduction in the IMR. The same trend had already been seen in the previous decade in the Federal District 11 and elsewhere in Brazil and Latin America 26,27.

Particularly noteworthy was the stagnation in the overall late neonatal mortality rate in the Federal District, due to the increase in some areas, indicating the need to adopt specific measures to directly impact this rate, such as interventions in maternal health conditions like nutritional and socioeconomic status, as well as improved prenatal, childbirth, and neonatal care 18,26.

Another possible explanation for the persistent late neonatal mortality rate is that neonatal intensive care and health technology can prolong the newborn's life, even in the face of decreased odds for longer-term survival 28.

Although maintaining the same rate of decline as in the previous decade, a decrease in the infant mortality rates was observed in various groups in the Federal District, which could be explained by the expanded coverage of specific health services such as immunization 12 and the promotion of breastfeeding 28 and extension of overall health services 13 . However, there were no substantially positive changes in the social structure. Such changes should be prioritized, with resource allocation, political determination, and social responsibility, aimed at effective interventions in both neonatal and post-neonatal mortality and an emphasis on perinatal problems related to maternal and infant health.

The downward trend in the IMR in the Federal District from 1990 to 2000 was similar to that in the 1980s 11 . However, when the rate was analyzed based on the five groups comprising the 19 administrative areas, key differences were identified, related to socioeconomic status and living conditions. In Groups 1 and 3 the IMR increased, while other groups showed a decrease, with the largest percentage change in Groups 2 and 5. The latter includes the "satellite cities" with the lowest mean family income and worst living conditions and is thus a top priority for interventions to effectively reduce infant mortality.

The data presented in this study showed an unexpected result when the 5 groups of administrative areas comprising the Federal District were 
analyzed. Despite evidence of the overall good quality of death records in the Federal District, incorrect information on place of residence can occur and lead to overestimation of mortality, especially in higher-income areas. Group 1 also includes a poor area that could tend to increase the number of deaths recorded there.

However, this evidence does not rule out the importance of socioeconomic variables, because although there was a reduction in the differences in IMR among the 5 groups of administrative areas, the highest IMR was in the group of administrative areas with the lowest income and vice versa (the lowest IMR in the highest income areas). An in-depth causal investigation is thus necessary.

According to a study by Sena 29 on breastfeeding prevalence in the Federal District, from 1994 and 1999 there was an increase in exclusive breastfeeding in all income groups, with the ex- ception of Group 1 (with a decrease of 9.3\%). The largest increase in average duration of exclusive breastfeeding was in Groups 2 (36.3\%) and 5 (103\%), and the latter had a longer mean duration of exclusive breastfeeding than Group 1.

Therefore, more effective measures to improve living and health conditions in these population groups are needed to avoid IMR stagnation at persistently high levels.

The current study thus helps elucidate infant mortality trends in the Federal District, an area of Brazil with some of the greatest social inequalities, combining migrants from poorly developed areas of the country and others with some of its highest per capita income. The results indicate the need for in-depth study of the various biosocial and economic variables affecting infant mortality, in order to plan and implement action strategies with real impact on the rates observed in the Federal District.

\section{Resumo}

O objetivo deste estudo é verificar a tendência da mortalidade infantil no Distrito Federal, Brasil, no período de 1990 a 2000 e descrevê-la, entre 1996 e 2000, nas cinco áreas do Distrito Federal estratificadas de acordo com a renda familiar média. Foi realizado um estudo ecológico de série temporal utilizando-se os Sistemas de Informação sobre Nascidos Vivos e Mortalidade produzidos pelo Ministério da Saúde. O coeficiente de mortalidade infantil (CMI) reduziu $45,2 \%$ entre 1990 e 2000, passando de 26,3 para 14,4 por mil nascidos vivos, sendo a taxa anual de decréscimo de 5,34\% $\left(R^{2}=0,9397 ; p<0,0001\right)$. Ocorreu no período maior proporção de óbitos no período neonatal, porém, o maior decréscimo ocorreu no componente pós-neonatal (-59\%, $\left.R^{2}=0,8452 ; p<0,0001\right)$. Quando avaliado o CMI nas diversas áreas do Distrito Federal, observa-se que houve uma redução na diferença entre as regiões no que diz respeito a seus componentes, porém foram mantidas distorções importantes quanto à variável renda. Os resultados sugerem que há necessidade de intervenção efetiva nos determinantes da mortalidade infantil e seus componentes que resulte na melhoria da saúde materno-infantil em todos os grupos sócioeconômicos do Distrito Federal.

Mortalidade Infantil; Saúde Materno-Infantil; Sistemas de Informação; Estudos Ecológicos

\section{Contributors}

Both authors participated in the article's design. R. A. Monteiro conducted the literature review and wrote the first draft, which was reviewed and received original contributions by B. A. S. Schmitz. Both authors reviewed and approved the final version.

\section{Acknowledgements}

The authors wish to thank Delmason Carvalho from the Federal District Health Secretariat for providing key data and documents for the study, as well as Gertrudes Mendonça, Ana Maria Nogales, and Eduardo Freitas for suggestions on statistical analysis. 


\section{References}

1. Campos TP, Carvalho MS, Barcellos CC. Mortalidade infantil no Rio de Janeiro, Brasil: áreas de risco e trajetória dos pacientes até os serviços de saúde. Rev Panam Salud Pública 2000; 8:164-71.

2. Mello-Jorge MHP, Gotlieb SLD, Laurenti R. A saúde no Brasil: análise do período 1996 a 1999. Brasília: Organização Pan-Americana da Saúde; 2001.

3. Simões CCS. Perfis de saúde e de mortalidade no Brasil: uma análise de seus condicionantes em grupos populacionais específicos. Brasília: Organização Pan-Americana da Saúde; 2002.

4. Mendonça G. Análise da evolução da mortalidade infantil em Portugal. Arquivos do Instituto Nacional de Saúde 1996; 22:29-31.

5. Ministério da Saúde. Indicadores e dados básicos - Brasil 2004. http://tabnet.datasus.gov.br/cgi/ idb2004/c01.htm (accessed on 03/Jan/2006).

6. Becker RA, Lechting A. Mortalidade infantil no Brasil. Ars Cvrandi 1988; 21:68-72.

7. Barreto ML, Carmo EH. Situação de saúde da população brasileira: tendências históricas, determinantes e implicações para as políticas de saúde. Inf Epidemiol SUS 1994; 3/4:7-34.

8. Szwarcwald CL, Leal MC, Castilho EA, Andrade CLT. Mortalidade infantil no Brasil: Belíndia ou Bulgária? Cad Saude Publica 1997; 13:503-16.

9. Simões CCS, Monteiro CA. Tendência secular e diferenciais regionais da mortalidade infantil no Brasil. In: Monteiro CA, organizador. Velhos e novos males da saúde no Brasil: a evolução do país e suas doenças. 2a Ed. São Paulo: Editora Hucitec/ Núcleo de Pesquisa Epidemiológicas em Nutrição e Saúde; 2000. p. 153-6.

10. Fundo das Nações Unidas para a Infância. Situação da infância brasileira 2001: desenvolvimento infantil. Brasília: Fundo das Nações Unidas para a Infância; 2001.

11. Schmitz BAS, Bezerra VLVA, Turnes O. Mortalidade infantil no Distrito Federal (Brasil): 1980-1989. Rev Saúde Dist Fed 1998; 9:13-22.

12. Anuário Estatístico do Distrito Federal, 2000 [CDROM]. Brasília: Secretaria do Estado de Desenvolvimento Urbano e Habitação; 2002.

13. Instituto Brasileiro de Geografia e Estatística. Base de informações por setor censitário: censo demográfico 2000 - resultados do universo. São Paulo: Instituto Brasileiro de Geografia e Estatística; 2002.

14. Programa das Nações Unidas para o Desenvolvimento. Relatório do desenvolvimento humano 2002: aprofundar a democracia num mundo fragmentado. Lisboa: Mensagem; 2002.

15. Ministério da Saúde. Atividades e funções do sistema de informação - DF (SIS). Brasília: Departamento de Saúde Pública, Secretaria de Saúde do Distrito Federal/Ministério da Saúde; 2001.

16. Szwarcwald CL, Leal MC, Andrade CLT, Souza Jr. PRB. Estimação da mortalidade infantil no Brasil: o que dizem as informações sobre óbitos e nascimentos do Ministério da Saúde? Cad Saúde Pública 2002; 18:1725-36.
17. Vasconcelos AMN. Qualidade das estatísticas de óbitos no Brasil: uma classificação das unidades da federação. In: Anais XII Encontro de Estudos Populacionais da ABEP [CD-ROM]. Campinas: Associação Brasileira de Estudos Populacionais; 2000.

18. Rede Interagencial de Informações para a Saúde. Indicadores básicos para a saúde no Brasil: conceitos e aplicações. Brasília: Organização Pan-Americana da Saúde; 2002.

19. Companhia do Desenvolvimento do Planalto Central. Perfil sócio-econômico das famílias do Distrito Federal. Brasília: Companhia do Desenvolvimento do Planalto Central; 1997.

20. Latorre MRDO, Cardoso MRA. Análise de séries temporais em epidemiologia: uma introdução sobre os aspectos metodológicos. Rev Bras Epidemiol 2001; 4:145-52.

21. Leal MC, Szwarcwald CL. Evolução da mortalidade neonatal no Estado do Rio de Janeiro, Brasil, de 1979 a 1993. 1- Análise por grupo etário segundo região de residência. Rev Saúde Pública 1996; 30:403-12.

22. Andrade CL, Szwarcwald CL, Gama SGN, Leal MC. Desigualdades sócio-econômicas do baixo peso ao nascer e da mortalidade perinatal no Município do Rio de Janeiro, 2001. Cad Saúde Pública 2004; 20 Suppl 1:S44-51.

23. Guimarães MJB, Marques NM, Melo Filho DA, Szwarcwald CL. Condição de vida e mortalidade infantil: diferenciais intra-urbanos no Recife, Pernambuco, Brasil. Cad Saúde Pública 2003; 19:1413-24.

24. Caldeira AP, França E, Perpétuo IHO, Goulart AM. Evolução da mortalidade infantil por causas evitáveis, Belo Horizonte, 1984-1998. Rev Saúde Pública 2005; 39:67-74.

25. Goldani MZ, Barbieri MA, Bettiol H, Barbieri MR, Tomkins A. Infant mortality rates according to socioeconomic status in a Brazilian city. Rev Saúde Pública 2001; 35:256-61.

26. Holcman MM, Latorre MRDO, Santos JLF. Evolução da mortalidade infantil na região metropolitana de São Paulo, 1980-2000. Rev Saúde Pública 2004; 38:180-6.

27. Maranhão AGK, Joaquim MMC, Siu C. A mortalidade perinatal e neonatal. Brasília: Ministério da Saúde/Fundo das Nações Unidas para a Infância; 1998.

28. Goldani MZ, Benatti R, Silva AAM, Bettiol H, Correa JCW, Tietzmann M, et al. Narrowing inequalities in infant mortality in Southern Brazil. Rev Saúde Pública 2002; 36:478-83.

29. Sena MCF. O aleitamento materno no Distrito Federal nos anos 90. Brasília: Fundação de Ensino e Pesquisa em Ciências da Saúde, 2002.

Submitted on $27 / J u n / 2005$

Final version resubmitted on 13/Jan/2006

Approved on 05/May/2006 